\title{
The efficacy of culling seals seen preying on seabirds as a means of reducing seabird mortality
}

\author{
Azwianewi B. Makhado ${ }^{1,2 *}$, Mike A. Meÿer ${ }^{1}$, Robert J. M. Crawford ${ }^{1,2}$, Les G. \\ Underhill $^{2}$ and Chris Wilke ${ }^{1}$ \\ ${ }^{1}$ Branch Marine and Coastal Management, Department of Environmental Affairs and Tourism, Private Bag X2, Rogge Bay 8012, South Africa and \\ ${ }^{2}$ Animal Demography Unit, Department of Zoology, University of Cape Town, Rondebosch 7701, South Africa
}

\begin{abstract}
In the 2006/2007 breeding season of Cape gannets Morus capensis at Malgas Island, the removal of 61 Cape fur seals Arctocephalus pusillus pusillus that preyed on gannet fledglings when they left to sea significantly reduced the mortality rate of these fledglings. However, because seals learned to avoid the boat used for their removal, it was not possible to remove all the seals that killed gannet fledglings and some mortality continued. The seals inflicting the mortality were all sub-adult males, with an average age of $<5$ years. Sustained removal of these animals may reduce this feeding behaviour, which is at present having an adverse impact on several threatened seabirds in the Benguela ecosystem.
\end{abstract}

Key words: Arctocephalus pusillus, Cape fur seal, Cape gannet, culling, fledgling mortality, Morus capensis, predation

\section{Résumé}

Lors de la saison de reproduction 2006/2007 des fous du Cap Morus capensis sur l'île de Malgas, le fait d'enlever 60 phoques à fourrure du Cap Arctocephalus pusillus pusillus qui se nourrissaient des jeunes fous au moment où ceux-ci partaient en mer a significativement réduit le taux de mortalité de ces jeunes. Cependant, comme les phoques ont appris àeviter les bateaux qui servent à les enlever, il ne fut pas possible d'enlever tous les phoques qui tuaient des jeunes fous, et une certaine mortalité s'est poursuivie. Les phoques responsables de la mortalitéétaient des mâles subadultes dont l'âge moyen était inférieur à cinq ans. Le prélèvement soutenu de ces animaux pourrait réduire ce comportement alimentaire qui est en train d'avoir un effet

*Correspondence: E-mail: amakhado@deat.gov.za négatif sur plusieurs oiseaux de mer menacés dans l'écosystème du Benguela.

\section{Introduction}

Over the past decades, many native vertebrate species have increased in abundance (Garrott, White \& White, 1993), whereas others have declined because of anthropogenic habitat changes (Reid \& Miller, 1989; World Conservation Monitoring Centre, 1992). Overabundant species (Wagner \& Seal, 1992; Garrott et al., 1993) have contributed to the decline of rare vertebrates through predation, competition, habitat change, disease transmission and hybridization (Caughley, 1981; Jenks \& Wayne, 1992; Wagner \& Seal, 1992; Garrott et al., 1993). The control of populations of these abundant species and their harmful effects on other species has received close attention (Jewell, Holt \& Hart, 1981; McCullough \& Barrett, 1992; Garrott et al., 1993; Harris \& Saunders, 1993). It is a common concern in efforts to recover endangered species (Goodrich \& Buskirk, 1995; Yodzis, 2001).

Off western South Africa, culling of Cape fur seals Arctocephalus pusillus pusillus seen preying on seabirds has been undertaken in an effort to limit the mortality of seabirds, several of which have an unfavourable conservation status (David et al., 2003). Cape fur seals are opportunistic animals that have benefited from several human activities. For example, they utilize fish discarded by fishing boats and take fish from fishers (e.g. Wickens et al., 1992). Subsequent to the elimination of some large mammalian predators from much of the southern African coastline, and to the exclusion of humans from diamond areas along the coast, large breeding colonies of Cape fur seals have formed at several sites on the mainland (e.g. Kirkman et al., 2007). The population of Cape fur seals increased markedly 
during the 20th century (Butterworth et al., 1995). By contrast, several seabirds, such as the African penguin Spheniscus demersus, are specialist feeders that compete with fisheries for food, had their breeding habitat altered inter alia through the removal of deposits of guano for agricultural use, and decreased substantially during the 20th century (Hockey, Dean \& Ryan, 2005 and references therein). Recent interactions between seals and seabirds off southern Africa are exacerbating the population decreases in seabirds caused by human perturbation of the marine ecosystem (e.g. Crawford et al., 1989; David et al., 2003). For example, at Malgas Island, in three seasons between 2000/2001 and 2005/2006, Cape fur seals killed 28$83 \%$ (average $56 \%$ ) of Cape gannets Morus capensis fledged at the island, a mortality rate that is considered unsustainable (Makhado, Crawford \& Underhill, 2006).

In the southern African situation, much of the predation of seabirds by seals was thought to be attributable to a few rogue seals; mostly males aged 2-10 years (David et al., 2003). It was hoped that the removal of these individual seals would substantially lessen their impact on seabirds but, in the longer-term, this proved not to be the case. Mortality increased to unsustainable levels in seasons following removal of the rogue seals (Makhado et al., 2006). This necessitated further investigations on the long-term effect of removal of rogue seals on seabird mortality. Therefore, at the conclusion of the 2006/2007 breeding season for Cape gannets, more observations were conducted at Malgas Island $\left(33^{\circ} 03^{\prime} \mathrm{S}, 17^{\circ} 55^{\prime} \mathrm{E}\right)$ off western South Africa and are reported in this paper. The paper also presents additional information on the sex and age of seals inflicting the mortality, investigates how the proportion of fledglings killed is related to the number of seals that hunt them and explores the dependency of seals on seabirds as a food source by examining the extent of carcase utilization by the seals.

\section{Methods}

From 5-12 February and 15-18 February 2007, estimates were made at Malgas Island of the number of Cape gannet fledglings entering the sea and of the number of fledglings killed by Cape fur seals. In the first of these periods, a team based at the island shot, under permit, the seals that were searching for or killing Cape gannet fledglings. No culling was undertaken in the second period.

The number of gannet fledglings entering the water and the number killed by seals were recorded by two observers, who kept watch from vantage points over different areas around the island during the same alternate hours, commencing at 08.00 hours and concluding at 18.00 hours. The vantage points allowed all fledglings entering the sea and all predation events during the periods of observation to be recorded.

On the first visit, an inflatable boat was used to patrol around the island and was guided by two-way radio to the site of a predation event, where an experienced marksman attempted to shoot the seal that had killed a gannet fledgling. An attempt was made to retrieve the carcases of all culled seals and killed gannets using gaffs. For each day, the total numbers of shots fired and seals killed, including those that were not retrieved, were recorded.

The sex of all seals that were shot was determined from the profile of their heads and necks, using features described by Apps (2000). The nose of males is more pointed, their neck thicker and their flipper is broader (M. A. Meÿer, personal observations). The standard lengths (American Society of Mammalogists, 1967) and axillary girths of all seals collected were measured. The ages of culled seals were estimated from size, based on previous experience with known age individuals (Miller, Oosthuizen \& Wickens, 1996). None of the collected seals was weighed, but mass $(M, \mathrm{~kg})$ was estimated from measurements of length $(L, \mathrm{~cm})$ and axillary girth $(G, \mathrm{~cm})$ using the relationship developed by Castellini \& Kooyman (1990) and Castellini \& Calkins (1993):

$$
M=4.57 \times 10^{-5}\left[L G^{2}\right] .
$$

The mass and condition of carcases of gannet fledglings, which were recovered, was recorded. The average mass of Cape gannet chicks at fledging is $2.9 \pm 0.3 \mathrm{~kg}$ (Jarvis, 1974; Batchelor \& Ross, 1984; Navarro, 1991). In most instances, seals were still feeding on the carcases at the time of their collection, so the extent of carcase utilization by seals will be underestimated.

A Chi-squared test was used to compare the proportions of Cape gannet fledglings that were killed by seals in the periods 5-12 February and 15-18 February. The Chisquared statistic was calculated as:

$$
\chi_{\text {calc }}^{2}=\sum_{i=1}^{k} \frac{\left(x_{i}-n_{i} \bar{p}\right)^{2}}{n_{i} \overline{p q}}
$$

where $x_{i}$ is the number of chicks killed in period $i ; n_{i}$ is the total number of chicks going to sea in period $i ; \bar{p}$ is the proportion of all chicks killed $\left\{\bar{p}=\sum x_{i} / \sum n_{i}\right\} ; \bar{q}$ is the proportion of all chicks not killed $\{\bar{q}=1-\bar{p}\}$ and $k=2$. 
We used a generalized linear model with a binomial distribution and the logit transformation to explore the relationship between the proportions of gannets in the water that were killed by seals and two explanatory variables: the number of shots fired on the previous day and the estimated daily number of seals engaging in killing gannets. The latter values were estimated by backcasting from the number of predatory seals that remained alive at the end of the cull and adding to this the numbers killed each preceding day.

\section{Results}

The number of Cape gannet fledglings observed entering the sea showed substantial variation about a mean value of 161 per day (SD = 73) (Table 1$)$. The number of gannet fledglings observed killed by seals decreased from 61 on 8 February to zero on 11 February but increased again to 32 on 18 February (Table 1). The percentage of fledglings entering the sea that was killed by seals decreased from 16\% during 5-11 February to 7\% during 15-18 February. Both the number $(r=-0.29, P=0.41, \mathrm{n}=10)$ and proportion $(r=-0.43, P=0.21, \mathrm{n}=10)$ of fledglings killed were negatively related to time. A significantly lower proportion of fledglings was killed in the postculling period of observations than during the period of culling $\left(\chi^{2}=31.15, P<0.001\right.$, df $\left.=1\right)$.

The number of seals culled fell during the period of the cull, from a peak of 25 individuals on day 2 to zero on the final day (Table 1). In total, 61 seals were shot and killed. It was estimated that further four seals were still killing gannet fledglings, but the boat was not able to approach them sufficiently close enough to shoot them.

The backcasting approach to estimating daily numbers of predatory seals suggested that on 5 February, the first day of the cull, there were 65 seals engaged in killing gannets (Table 1). The generalized linear model accounted for $51.6 \%$ of the deviance: both the estimated number of predatory seals (positive effect) and the number of shots fired the previous day (negative effect) had a significant impact on the proportion of gannet fledglings killed (both $P<0.001$ ) (Table 2):

$$
\begin{aligned}
\operatorname{logit} P= & -2.40+0.034 \times \text { seals alive on the day } \\
& -0.034 \times \text { shots fired previous day, }
\end{aligned}
$$

where $P=$ is the proportion of gannet fledglings killed.

For the 61 seals shot, the estimated average age was 4.8 years $(\mathrm{SD}=1.4)$. It ranged between 2 and 8 years. For the 33 that were retrieved, the estimated average age was

Table 2 Results of the generalized linear model relating the proportion of fledgling Cape gannets killed around Malgas Island during 10 days in February 2007 with two explanatory variables

\begin{tabular}{llllll}
\hline & \multicolumn{1}{c}{ Regression } & & & \\
Explanatory variable & estimate & SD & $t$ & $P$-value \\
\hline Constant & -2.403 & 0.123 & -19.5 & $<0.001$ \\
Estimated no. predatory & 0.03393 & 0.00379 & 8.94 & $<0.001$ \\
$\begin{array}{l}\text { seals alive the same day } \\
\text { No. shots fired the }\end{array}$ & -0.03361 & 0.00668 & -5.03 & $<0.001$ \\
previous day & & & & \\
\hline
\end{tabular}

The model accounted for $51.6 \%$ of the deviance.

Table 1 Numbers of Cape gannet fledglings entering the sea and killed by seals, numbers of seals alive and shot, percentages of Cape

\begin{tabular}{|c|c|c|c|c|c|c|}
\hline Date & $\begin{array}{l}\text { No. gannet } \\
\text { fledglings } \\
\text { entering water }\end{array}$ & $\begin{array}{l}\text { No. gannet } \\
\text { fledglings } \\
\text { killed by seals }\end{array}$ & $\begin{array}{l}\text { No. seals } \\
\text { shot } \\
\text { during day }\end{array}$ & $\begin{array}{l}\text { No. seals } \\
\text { alive at } \\
\text { start of day }\end{array}$ & $\begin{array}{l}\% \text { of } \\
\text { birds } \\
\text { killed }\end{array}$ & $\begin{array}{l}\text { No. shots } \\
\text { fired the } \\
\text { previous day }\end{array}$ \\
\hline 05 Feb 2007 & 0 & 5 & 5 & 65 & 0 & 8 \\
\hline 06 Feb 2007 & 157 & 43 & 25 & 60 & 27.38 & 8 \\
\hline 07 Feb 2007 & 225 & 11 & 4 & 35 & 4.88 & 45 \\
\hline 08 Feb 2007 & 234 & 61 & 18 & 31 & 26.07 & 11 \\
\hline 09 Feb 2007 & 97 & 2 & 4 & 13 & 2.06 & 36 \\
\hline 10 Feb 2007 & 76 & 17 & 5 & 9 & 22.37 & 6 \\
\hline 11 Feb 2007 & 61 & 0 & 0 & 4 & 0 & 16 \\
\hline 15 Feb 2007 & 167 & 2 & 0 & 4 & 1.19 & 0 \\
\hline 16 Feb 2007 & 112 & 2 & 0 & 4 & 1.79 & 0 \\
\hline 17 Feb 2007 & 203 & 19 & 0 & 4 & 9.36 & 0 \\
\hline 18 Feb 2007 & 275 & 32 & 0 & 4 & 11.64 & 0 \\
\hline
\end{tabular}
gannet fledglings in the water that were killed by seals and number of seals killed, for each day of observation 
4.7 years $(\mathrm{SD}=1.5)$. All animals retrieved were males Their average length was $141.2 \mathrm{~cm}(\mathrm{SD}=17.6)$ and their average axillary girth was $86.4 \mathrm{~cm}(\mathrm{SD}=12.6)$. Using the allometric equation to estimate mass, their average mass was found to be $50.8 \mathrm{~kg} \quad(\mathrm{SD}=22.4$, range 19.5 $123.7 \mathrm{~kg})$.

In total, 61 carcases of gannet fledglings that had been killed by seals were retrieved. The average mass of these was $2.2 \mathrm{~kg}(\mathrm{SD}=0.4)$. About $50 \%$ of the retrieved carcasses were without breast muscles and viscera. For about $20 \%$ of the carcases, only the viscera had been eaten. About $7.5 \%$ of the carcasses had been fully utilized.

\section{Discussion}

Protecting threatened species from extinction requires management interventions, which may involve the removal of problem predators (David et al., 2003). Where individual rogue animals are causing the problem, their specific removal should eliminate the problem, as long as measures are put into place to discourage other animals from becoming problems in the future (National Marine Fisheries Service, 1996). For example, the removal of three troublesome California sea lions Zalophus californianus at Ballard Locks, Seattle, to a captive facility (National Oceanic and Atmospheric Administration, 1996) and the use of acoustic alarms (Marine Mammal Commission, 2000) reduced depredations by sea lions on steelhead trout Oncorhynchus mykiss passing through the locks on their way to spawning grounds up river (National Oceanic and Atmospheric Administration, 1999).

Culls of seals eating gannet fledglings around Malgas Island rapidly reduced the mortality rate in 1999 and 2000 (David et al., 2003) and similarly around Ichaboe Island in Namibia (Du Toit et al., 2004). In this study, the removal of 61 seals inflicting mortality on Cape gannet fledglings resulted in an immediate reduction in the mortality rate confirming that culling rogue animals is an effective way to reduce seabird mortality in the short term. However, predation of gannet fledglings recommenced within a week of cessation of culling rogue seals (Table 1), in accordance with previous observations that the intervention might not have a beneficial effect in the long term. It is difficult to remove all the seals that are killing the birds because, after a period of culling, seals become wary of approach by a boat (M. A. Meÿer, personal observations). Hence, some seals that have developed a technique to hunt seabirds remain, with the potential to pass the technique on to younger animals.

It is possible that persistent culling of seals that eat seabirds may decrease this feeding behaviour of seals. Given that the average age of seals feeding on gannet fledglings at Malgas Island is estimated to be $<5$ years, it might be hoped that persistent removal of these individuals over a period of 5 years would largely eliminate the behaviour. In 1999/2000, 55\% of seals killing seabirds were 6 years and older compared to $24 \%$ in this study (Marine and Coastal Management, unpublished data). This reduced age of animals killing seabirds probably resulted from the removal of seals during 1999/2000.

Seabirds are not an important component of the diet of Cape fur seals (David et al., 2003; Mecenero, Kirkman \& Roux, 2005). Even for those individuals that have learnt to catch seabirds, the often poor utilization of carcasses (David et al., 2003) suggests that seabirds are not essential in the diet and hence that the behaviour might be stopped by the removal of all animals that are practising it.

To have a maximum beneficial effect, the seals killing birds should be removed before they have inflicted substantial mortality, for example when the fledging of Cape gannet chicks is commencing rather than late in the fledging period. In other species, for example during predation on penguins (Marks, Brooke \& Gildenhuys, 1997), the fledging period may not be as distinct.

Culling, defined as the directed reduction in the size of a population to achieve some specified objective (Jewell et al., 1981) may involve lethal or nonlethal methods of removal. Culling using nonlethal methods involves the capture of individual animals and their relocation elsewhere in the wild or their confinement in captivity (e.g. Fraker \& Mate, 1999). In the context of seals preying on seabirds off southern Africa, this is not regarded as a control option because no means of safely capturing wild Cape fur seals at sea have yet been developed. Previous efforts to condition Cape fur seals against certain behaviours also proved unsuccessful (Shaughnessy et al., 1981). Lethal culling may involve the targeted removal of offending individuals or the indiscriminant killing of large numbers of animals (essentially, culling at the population level) with a view to reducing the number or severity of interactions between the population being culled and other populations. As in this study, David et al. (2003) reported that all seals causing mortality of seabirds were sub-adult males. Hence, it is only a segment of the seal population that is having an adverse 
impact on southern Africa's seabird populations (see also Shaughnessy, 1978; Rebelo, 1984; Navarro, 2000; Du Toit et al., 2004; Mecenero et al., 2005), so that nonselective culling should be avoided. Indiscriminant culling at the population level will not necessarily remove the individuals that are implicated in the presumed interaction (Lavigne, 2003).

\section{Acknowledgements}

We thank our research institutes (listed under addresses), the National Research Foundation (SANAP programme) and WWF-SA for supporting this research. We are grateful to all who assisted with observations of mortality of Cape gannet fledglings and culling of seals, including L. Upfold, D Kotze and T. Nethononda. L. Antony assisted with the statistical analysis. The Department of Environmental Affairs and Tourism, South African National Parks and South African Navy provided logistical support for the surveys. This paper is a contribution to the project LMR/EAF/03/02 of the Benguela Current Large Marine Ecosystem (BCLME) Programme.

\section{References}

American Society of Mammalogists (1967) Standard measurements of seals. J. Mammal. 48, 459-462.

Apps, P. (2000) Smither's Mammals of Southern Africa: Field Guide. Struik, Cape Town.

Batchelor, A.L. \& Ross, G.J.B. (1984) The diet and implications of dietary change of Cape gannets on Bird Island, Algoa Bay. Ostrich 55, 45-63.

Butterworth, D.S., Punt, A.E., Oosthuizen, W.H. \& Wickens, P.A. (1995) The effects of future consumption by the Cape fur seal on catches and catch rates of the Cape hakes. 3. Modeling the dynamics of the Cape fur seal Arctocephalus pusillus pusillus. $S$. Afr. J. Mar. Sci. 16, 161-183.

Castellini, M.A. \& CALKINS, D.G. (1993) Mass estimates using body morphology in Steller sea lions. Mar. Mamm. Sci. 9, 48-54.

Castellini, M.A. \& Kooyman, G.L. (1990) Length, girth and mass relationships in Weddel seals (Leptonychotes weddellii). Mar. Mamm. Sci. 6, 75-77.

Caughley, G. (1981) Overpopulation. In: Problems in Management of Locally Abundant Wild Mammals (Eds P. A. JewelL, S. Holt and D. HART). Academic Press, New York.

Crawford, R.J.M., David, J.H.M., Williams, A.J. \& Dyer, B.M. (1989) Competition for space: recolonising seals displace endangered, endemic seabirds off Namibia. Biol. Conserv. 48, 59-72.

David, J.H.M., Cury, P., Crawford, R.J.M., Randall, R.M., UNDERHILL, L.G. \& MË̈ER, M.A. (2003) Assessing conservation priorities in the Benguela ecosystem, South Africa: analysing predation by seals on threatened seabirds. Biol. Conserv. 114, 289-292.

Du Toit, M., BARTlett, P.A., Bester, M.N. \& Roux, J.-P. (2004) Sealseabird predation at Ichaboe Island, Namibia: prey selection by individual seals. S. Afr. J. Wildl. Res. 34, 45-54.

Fraker, M.A. \& Mate, B.R. (1999) Seals, sea lions, and salmon in the Pacific Northwest. In: Conservation and Management of Marine Mammals (Eds J. R. Twiss Jr and R. R. ReEves). Smithsonian Institution Press, Washington, DC.

Garrott, R.A., White, P.J. \& White, C.A.V. (1993) Overabundance: an issue for conservation biologists? Conserv. Biol. 7, 946-949.

GOODRICH, J.M. \& BusKIRK, S.W. (1995) Control of abundant native vertebrates for conservation of endangered species. Conserv. Biol. 9, 1357-1364.

Harris, S. \& SAUnders, G. (1993) The control of canid populations. Symp. Zool. Soc. Lond. 65, 441-464.

Hockey, P.A.R., DeAn, W.R.J. \& RYan, P.G. (2005) Roberts Birds of Southern Africa, 7th edn. John Voelcker Bird Book Fund, Cape Town.

JARvIS, M.J.F. (1974) The ecological significance of clutch size in the South African gannet (Sula capensis (Lichtenstein)). J. Anim. Ecol. 43, 1-17.

Jenks, S.M. \& WAyne, R.K. (1992) Problems and policy for species threatened by hybridization: the red wolf as a case study. In: Wildlife 2001: Populations (Eds D. R. McCulLough and R. H. BARRETT). Elsevier Applied Science, New York.

Jewell, P.A., Holt, S. \& Hart, D., Eds. (1981) Problems in Management of Locally Abundant Wild Mammals. Academic Press, New York.

Kirkman, S.P., Oosthuizen, W.H., MeŸER, M.A., KotZe, P.G.H., Roux, J.-P. \& UNDERHILL, L.G. (2007) Making sense of censuses dealing with missing data: trends in pup counts of Cape fur seal Arctocephalus pusillus pusillus for the period 1972-2004. Afr. J. Mar. Sci. 29, 161-176.

LAvigne, D.M. (2003) Marine mammals and fisheries: the role of science in the culling debate. In: Marine Mammals: Fisheries, Tourism and Management Issues (Eds N. GALES, M. HINDELL and R. KIRKWOOD). CSIRO Publishing, Collingwood, Australia.

MakHado, A.B., Crawford, R.J.M. \& UnderhiLl, L.G. (2006) Impact of predation by Cape fur seals Arctocephalus pusillus on Cape gannets Morus capensis at Malgas Island, Western Cape, South Africa. Afr. J. Mar. Sci. 28, 681-687.

Marine Mammal Commission (2000) Annual Report to Congress 1999. Marine Mammal Commission, Maryland.

Marks, M.A., BrooKe, R.K. \& GiLdenhuys, A.M. (1997) Cape fur seal Arctocephalus pusillus predation on Cape cormorants Phalacrocorax capensis and other birds at Dyer Island, South Africa. Mar. Ornithol. 25, 9-12.

McCullough, D.R. \& BarretT, R.H. (1992) Wildlife 2001: Populations. Elsevier Applied Science, New York.

Mecenero, S., Kirkman, S.P. \& Roux, J.-P. (2005) Seabirds in the diet of Cape fur seals Arctocephalus pusillus pusillus at three 
mainland breeding colonies in Namibia. Afr. J. Mar. Sci. 27, 509-512.

Miller, C.M., Oosthuizen, W.H. \& Wickens, P.A. (1996) Cape fur seals trapped in trawling gear: age structure, sex ratio, seasonality and distribution. S. Afr. J. Mar. Sci. 17, 105-111.

National Marine Fisheries Service (1996) Environmental assessment on conditions for lethal removal of California sea lions at the Ballard Locks to protect winter steelhead. NMFS Environ. Assess. Rep. 1-81.

NAtional Oceanic AND Atmospheric Administration (1996) National Marine Fisheries Service OK's Permanent Home for Seattle's Sea Lions at Sea World in Florida. NOAA, Available at: http:// www.publicaffairs.noaa.gov/pr96/apr96/noaa96-r130.html.

National Oceanic AND AtmosPheric Administration (1999) Steelhead-eating Sea Lions All But Gone from Seattle's Ballard Locks. NOAA, Available at: http://www.publicaffairs.noaa.gov/ releases99/may99/noaa99r128.html.

NAVARro, R.A. (1991) Food addition and twinning experiments in the Cape gannet: effects on breeding success and chick growth and behavior. Colon. Waterbirds 14, 92-102.

Navarro, R.A. (2000) Cape fur seal predation on Cape gannet fledglings. Bird Numbers 9, 15-16.

Rebelo, A.G. (1984) Cape fur seal Arctocephalus pusillus kills jackass penguin Spheniscus demersus on land. Cormorant 12, 111.

ReID, W.V. \& Mitler, K.R. (1989) Keeping Options Alive: The Scientific Basis for Conserving Biodiversity. World Research Institute, Washington, DC.
Shaughnessy, P.D. (1978) Cape fur seals preying on seabirds. Comorant 5, 31.

Shaughnessy, P., Semmelink, A., Cooper, J. \& Frost, P. (1981) Attempts to develop acoustic methods of keeping Cape fur seals, Arctocephalus pusillus, from fishing nets. Biol. Conserv. 21, 141158.

WAGneR, F.H. \& SEAL, U.S. (1992) Values, problems, and methodologies in managing overabundant wildlife populations: an overview. In: Wildlife 2001: Populations (Eds D. R. McCullough and R. H. Barrett). Elsevier Scientific Publications, London.

Wickens, P.A., Japp, D.W., Shelton, P.A., Kriel, F., Goosen, P.C., Rose, B., Augustyn, C.J., Bross, C.A.R., Penney, A.J. \& Krohn, R.G. (1992) Seals and fisheries in South Africa - competition and conflict. In: Benguela Trophic Functioning (Eds A. I. L. PAYNE, K. H. Brink, K. H. Mann and R. Hilborn). S. Afr. J. Mar. Sci. 12, 773-789.

World Conservation Monitoring Centre (1992) Global Biodiversity: Status of the Earth's Living Resources. Chapman and Hall, London.

YoDZIS, P. (2001) Must top predators be culled for the sake of fisheries? Trends Ecol. Evol. 16, 78-84.

(Manuscript accepted 12 February 2008)

doi: 10.1111/j.1365-2028.2008.00966.x 